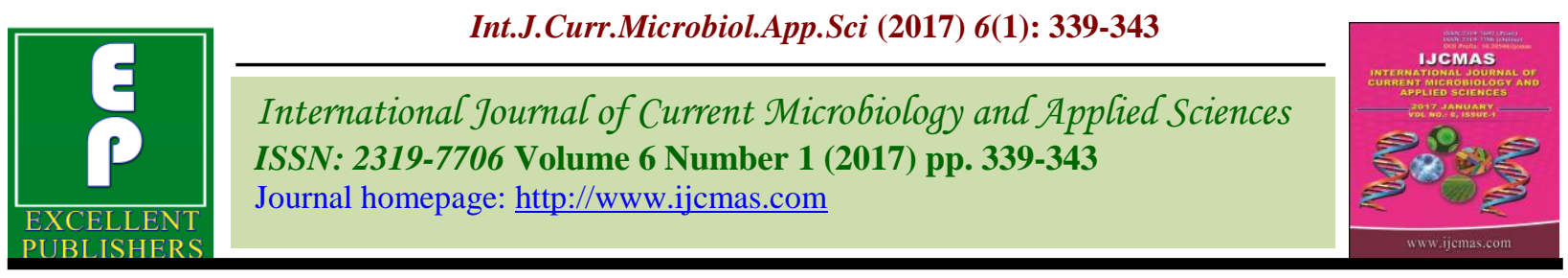

Original Research Article

http://dx.doi.org/10.20546/ijcmas.2017.601.041

\title{
Antimicrobial Susceptibility of Myristica fragrans Extract against Oral Pathogens
}

\author{
Abhilasha Singh ${ }^{1 *}$, Ritu Thakur Bais ${ }^{2}$ and Vinod Singh ${ }^{2}$ \\ ${ }^{1}$ Department of Microbiology, Barkatullah University, Bhopal, India \\ ${ }^{2}$ Department of Botany, Govt. M.L.B. College, Bhopal, India
}

*Corresponding author:

Keywords

Mysritica frangrans, plant extract, antibacterial activity.

\section{Article Info}

Accepted:

18 December 2016

Available Online:

10 January 2017

\section{A B S T R A C T}

\section{Introduction}

Myristica fragrans commonly known as Jaiphal and Javitri in India, belongs to the family Myristicaceae. It produces spice, nutmeg. This spice is used in Asian folk medicine to treat microbial pathogens. Depending on its origins, It contains the aroma compounds as like monoterpenes (87.5\%), monoterpene alcohols (5.5\%), and other aromatics (7\%) (Pooja et al., 2012). The oil of nutmeg has also been used for medicinal purposes and it is this fraction of the nutmeg which contains the pharmacologically active components (Kaushik and Singh, 2012). Narasimhan and Dhake, 2006 reported that trimyristin, an active compound obtained from seed of Myristica fragrans, also exhibited good antibacterial properties against Gram-positive and Gram negative bacteria. The great diversity of the chemical structures of secondary plant metabolites continues to provide new and important leads against several pharmacological targets (Porto, 2009). Several studies have demonstrated the great importance of natural products, both plant extracts and isolated compounds, as natural antibacterial agents in oral care products (Haffajee et al., 2008). Dental caries is a localized infectious disease that leads to loss of teeth. Individuals heavily colonized by 
cariogenic bacteria are considered to be at high risk for dental carie (Deshpande and Kadam, 2012). Caries and periodontal disease can be prevented by good maintenance of oral hygiene with the use of oral care products. Nowadays, there are high interests in oral care products that are incorporated with medicinal plant extracts and are used extensively by the consumers due to low toxicity compared to oral care products (Shafiei et al., 2012). The current study investigates the anti-microbial potential of Myristica fragrans against oral pathogens.

\section{Materials and Methods}

Plant material: Fresh and dry fruits of $M$. fragrans were collected from local market of Bhopal, India. The dry fruits were first identified by Dr. Manish Mishra, Indian Institute of Forest Management, Bhopal, India. The dried fruits were pulverized to a fine powder using a sterilized mixer grinder and stored in airtight polybegs. Methanol was used for extraction.

\section{Extraction of Bioactive Compound}

The pulverized samples of Myristica fragrans were extracted using Soxhlet extraction (Borosil) method with methanol. The extraction processes were carried out for 3 days to obtain crude extracts which were concentrated under reduced pressure by using a rotary evaporator. The resulting pellet was finally pounded to dryness at room temperature to concentrate crude extracts, respectively. The crude extract was then stored at $-20^{\circ} \mathrm{C}$ for use in further studies.

\section{Isolation of Oral Pathogens}

The dental plaque sample was inoculated on blood agar, MRS and Macconky plates and incubated for $18-24$ hours at $37^{\circ} \mathrm{C}$ streak plate technique and the pathogens were isolated and identified by Bergey's manual (Holt et al., 2000).

Statistical Analysis: The data from zones of inhibition of growth of each microorganism in different extracts concentrations were represented as mean \pm standard error.

\section{Results and Discussion}

After the bacteria were grown on Blood Agar plate, Macconky agar and MRS agar colonies with distinctive morphology were selected. Four colonies were selected for further study. All of the strains displayed positive gram staining reaction. Different biochemical tests for the presumptive identification of the isolated colonies were also performed. All of the strains were catalase negative. However, they exhibited differential hemolysis pattern on blood agar and distinctive reaction pattern for bile aesculin, bacitracin resistance, arginine hydrolysis and esculin hydrolysis tests.

The most frequently isolated species are Lactobacillus acidophillus, Streptococcus mutans, Streptococcus mitis and Entrococcus faecalis. The methanolic extract of $M$. fragrans subjected to preliminary screening for their antibacterial activity against four isolated bacterial species namely Lactobacillus acidophillus, Streptococcus mutans, Streptococcus mitis and Entrococcus faecalis. Methanolic extract showed high activity against gram positive. The diameter of inhibition zone reached $28 \pm 0.14 \mathrm{~mm}$ against $E$. faecalis concentration of $25 \mathrm{mg} / \mathrm{ml}$ and $24 \pm 0.002 \mathrm{~mm}$ for Streptococcus mitis at $50 \mathrm{mg} / \mathrm{ml}$ concentration (Table 1 \& Figure $1 \& 2)$. Many research studies are available which showed the prevention of dental plaque formation and on different compounds which possess antibacterial activity against oral bacteria (Sujatha et al., 2012). 
Table.1 Zone of inhibition of $M$. fragrans extract against different oral pathogens

\begin{tabular}{|l|l|l|l|l|}
\hline \multicolumn{1}{|c|}{ Test Microorganism } & \multicolumn{4}{|c|}{ Mean diameter of zone of Inhibition (mm) } \\
\hline & $25 \mathrm{mg} / \mathrm{ml}$ & $50 \mathrm{mg} / \mathrm{ml}$ & $75 \mathrm{mg} / \mathrm{ml}$ & $100 \mathrm{mg} / \mathrm{ml}$ \\
\hline Lactobacillus acidophilus & $16 \pm 0.002$ & $19 \pm 0.04$ & $16 \pm 0.028$ & $15 \pm 0.14$ \\
\hline Streptococcus mutans & $15 \pm 0.04$ & $16 \pm 0.04$ & $17 \pm 0.002$ & $16 \pm 0.04$ \\
\hline Streptococcus mitis & $16 \pm 0.007$ & $24 \pm 0.002$ & $11 \pm 0.002$ & $13 \pm 0.007$ \\
\hline Entrococcus faecalis & $28 \pm 0.14$ & $15 \pm 0.007$ & $13 \pm 0.002$ & $19 \pm 0.007$ \\
\hline
\end{tabular}

Fig.1 Antimicrobial activity of $M$. fragrans against oral pathogens

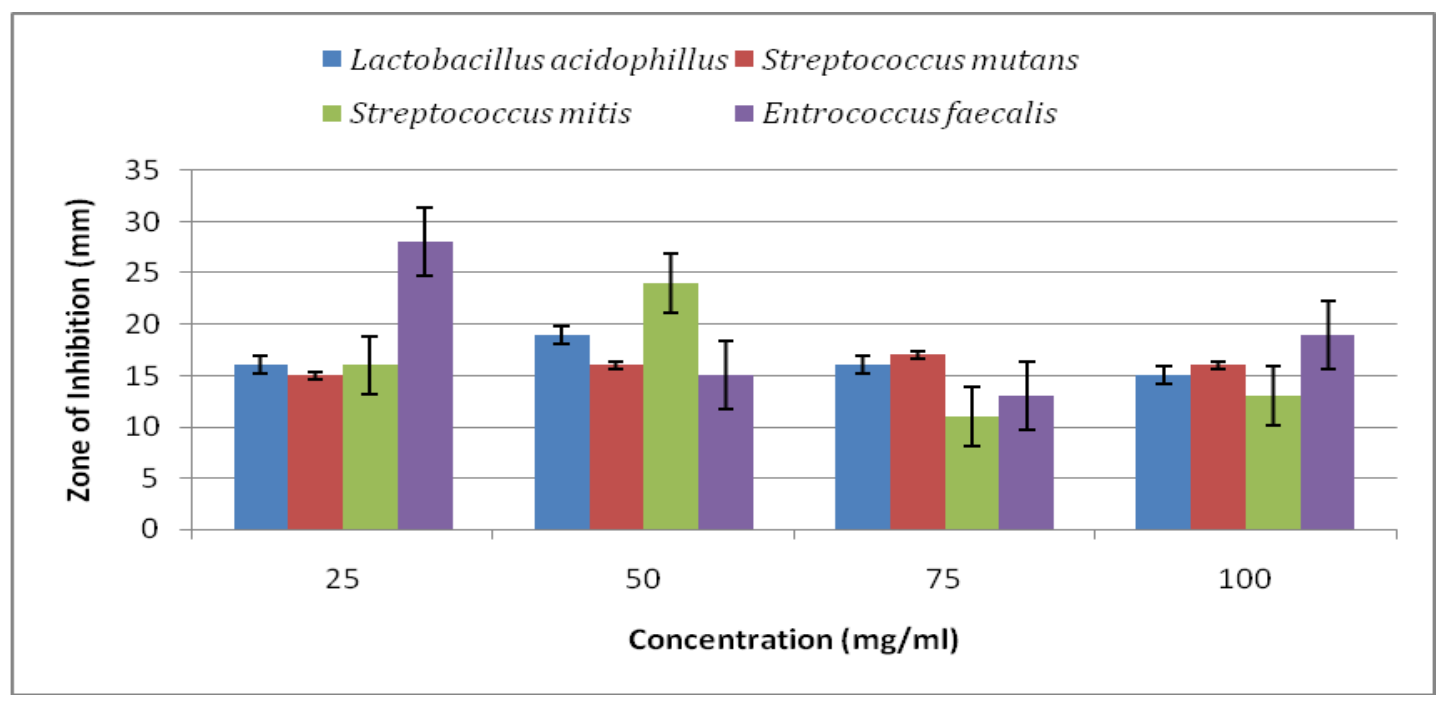

Fig.2 Antimicrobial activity of M. fragrans against oral pathogens (A) L. acidophilus (B) S. mitis (C) E. feacalis (D) S. mutans

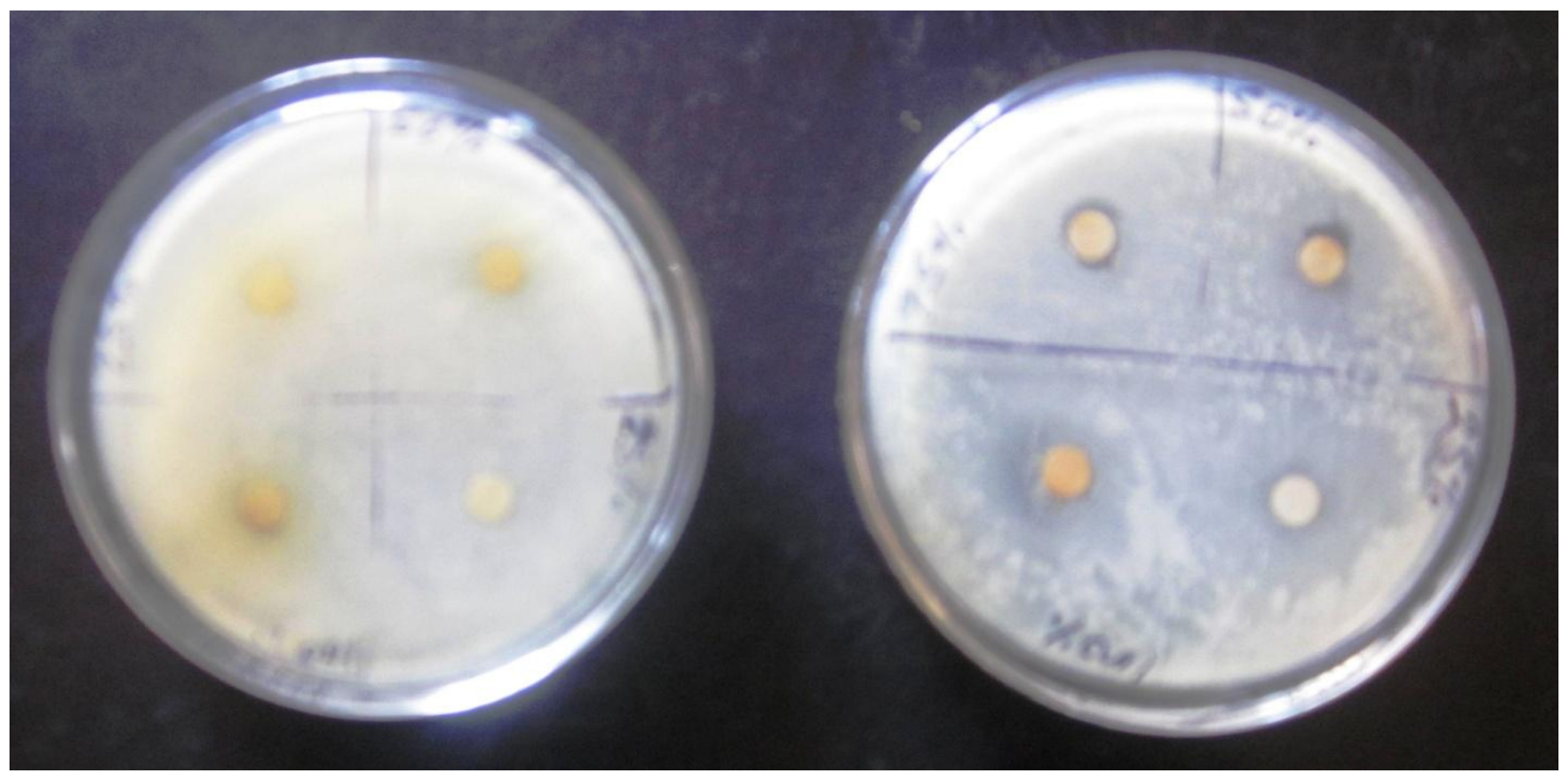




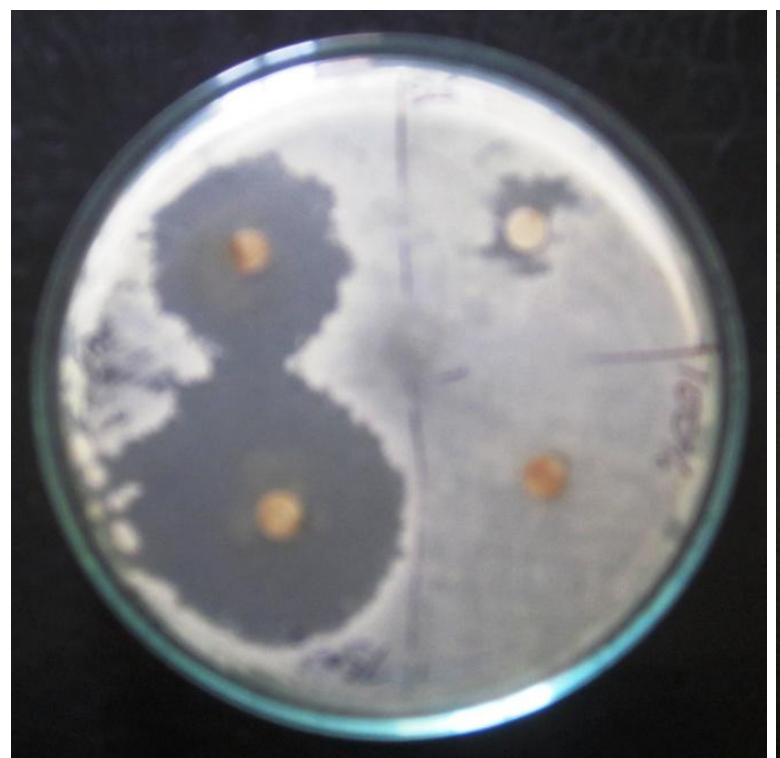

The results obtained from these study support the antimicrobial activity in the previous reports by Piaru et al., 2012. Nutmeg oil contains monoterpenes such as -pinene, camphene, -pinene, sabinene, myrcene, aphellandrene, a-terpinene, limonene, 1, 8cineole, g-terpinene, linalool, terpinen-4-ol, safrole, methyl eugenol and myristicin, as their active principles. Their mode of antimicrobial action is related to their ability to inactivate microbial adhesion, enzymes and cell envelope proteins (Ibrahim, et al., 2013). The medicinal properties of plant species have made an outstanding contribution in the origin and evolution of many traditional herbal therapies. Over the past few years, medicinal plants have regained a wide recognition due to an escalating faith in herbal medicine. In view of its lesser side effects compared to allopathic medicine in addition, the necessity of meeting the requirements of medicine for an increasing human population (Akrayi, 2012).

In conclusion, it can be concluded from the results that methanol extract of $M$. fragrans possess significant antibacterial activity against tested oral bacteria. However, the active components responsible for the antimicrobial activities need to be evaluated further. The antibacterial that are currently

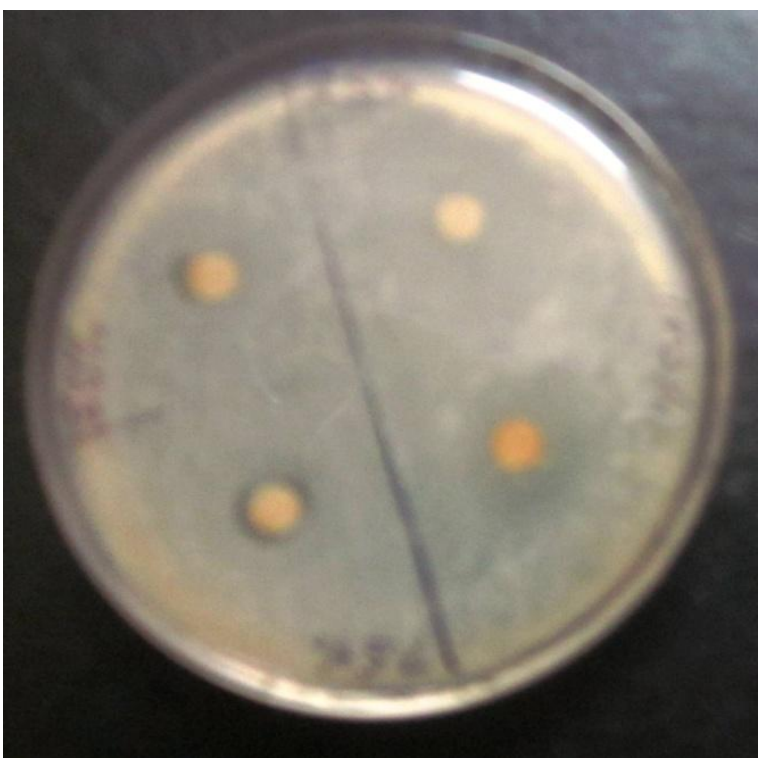

used suffer from several drawbacks such as high toxicity, low absorption, and high cost of treatment. The area of antibacterial drug discovery is at a nascent stage. The challenge in antibacterial drug discovery is its high toxicity in humans. Therefore the search for alternate treatment modalities is the need of the hour.

\section{References}

Akrayi, H. 2012. Effect of Some Plant Extracts on Isolated Bacteria from Eyelids of Natural Eye liner Users and Eye Cosmetics Users. J. Appl. Pharma. Sci., 2 (11), 003-008.

Deshpande, S.N., Kadam, D.G. 2012. Phytochemical analysis and antibacterial activity of Acacia nilotica against streptococcus mutans. Int. J. Pharm. Pharm. Sci., 5(1): 236-238.

Haffajee, A.D., Yaskell, T., Socransky, S.S. 2008. Antimicrobial effectiveness of an herbal mouthrinse compared with an essential oil and a chlorhexidine mouthrinse. J. Am. Dent. Assoc., 139: 609-611.

Holt, J.G., Krieg, N.R., Sneath, P.H.A., Staley, J.T., Williams, S.T. 2000. Streptococcus and Fusobacterium, in Bergeys manual of determinative 
bacteriology edited by William $\mathrm{R}$ Henayl, (Lippincott Williams \& Wilkins, New York, 296 \& 532.

Ibrahim, K.M., Naem, R.K. and Abd-Sahib, A.S. 2013. Antibacterial Activity of Nutmeg. Myristica fragrans. Seed Extracts against Some Pathogenic Bacteria. J. Al-Nahrain Univ., 16(2), 188-192.

Kaushik, S. and Singh, P. 2012. Antibacterial Activity of Different Extracts of Nutmeg. Myristica fragrans. Against Gram Negative and Gram Positive Pathogens. Vegetos, 25(2): 282-286.

Narasimhan, B. and Dhake, A.S. 2006. Antibacterial principles from Myristica fragrans seeds. J. Medic. Food, 9(3), 395-399.

Piaru, S.P., Mahmud, R. and Perumal, S. 2012. Determination of antibacterial activity of essential oil of Myristica fragrans. Int. J. Pharma.

Pooja, V., Goyal, S., Bhatnagar, A. and
Srivastava, A.K. 2012. Activity of Myristica fragrans and its effect against filamentous and non-filamentous fungus. Int. J. Pharma. Pharma. Sci., 4(1).

Porto, T.S., Rangel, R., Furtado, Tatiane, C. de Carvalho, Carlos, H.G. Martins, Rodrigo, C.S. Venezian, Fernando, B. Da Costa, Adriana, H.C. Vinholis. 2009. Pimarane-type Diterpenes: Antimicrobial Activity against Oral Pathogens. Molecu., 14, 191-199.

Shafiei, Z., Shuhairi, N.N., Nordiyana, Md Fazly Shah Yap, Sibungkil, C.A.H., and Latip, J. 2012. Antibacterial Activity of Myristica fragrans against Oral Pathogens. Evi.-Based Compl. Alter. Med., 1-7.

Sujatha, L., Govardhan, T.L., Rangaiah, G.S. 2012. Antibacterial activity of green seaweeds on oral bacteria. Ind. J. Nat. Prod. Resou., 3(3), 328-333.

\section{How to cite this article:}

Abhilasha Singh, Ritu Thakur Bais and Vinod Singh. 2017. Antimicrobial Susceptibility of Myristica fragrans Extract against Oral Pathogens. Int.J.Curr.Microbiol.App.Sci. 6(1): 339343. doi: http://dx.doi.org/10.20546/ijcmas.2017.601.041 